\title{
Review
}

Source: The Musical Times and Singing Class Circular, Vol. 31, No. 573 (Nov. 1, 1890), p. 680 Published by: Musical Times Publications Ltd.

Stable URL: http://www.jstor.org/stable/3364932

Accessed: 25-04-2016 02:22 UTC

Your use of the JSTOR archive indicates your acceptance of the Terms \& Conditions of Use, available at

http://about.jstor.org/terms

JSTOR is a not-for-profit service that helps scholars, researchers, and students discover, use, and build upon a wide range of content in a trusted digital archive. We use information technology and tools to increase productivity and facilitate new forms of scholarship. For more information about JSTOR, please contact support@jstor.org.

Musical Times Publications Ltd. is collaborating with JSTOR to digitize, preserve and extend access to The Musical Times and Singing Class Circular 
notes, considering how the present method has been sanctified by time; but we earnestly counsel thoughtful teachers to make a trial of Miss Mundella's book, and be guided only by experience as to the result. We may say that the melodious nature of all the duets contained in the volume will delight juvenile pianists, and that the ingenious manner in which the teacher's part is woven in with that for the pupil can scarcely fail to win the cordial approval of every sympathetic listener.

The Golden Fleece, a humorous Cantata; and The Lord of Gold, a sacred Cantata. By Edmund Rogers.

[Glasgow: Bayley and Ferguson.]

THE versatility of the composer is cleverly shown in these two Cantatas. There is a considerable amount of grace of melody interwoven with the humorous thoughts of the author of the book of "The Golden Fleece" (Mr. Joseph Despicht). The fun is genuine and hearty, and the whole treatment, inspired, as one cannot help thinking, by a study of the Gilbert and Sullivan productions, will find, as it deserves to find, much favour.

"The Lord of Gold" is an adaptation of the story of Daniel, set to effective but by no means difficult music, so that it forms an excellent addition to the number of Cantatas suitable for use in Church, for which there is now a growing demand.

Practical Hints on Boy Choir Training. By J. Edward Stubbs. [Novello, Ewer and Co.]

Mr. Stubis, the Organist and Choirmaster of St. James's Church, New York, deserves the heartiest thanks of all who are interested in the subject of which he treats. $\mathrm{His}$ remarks are sensible, reasonable, and to the point, and whether in dealing with the facilities for carrying on choir work, or in describing the characteristics of the boy's voice, vocal training, or pronunciation, phrasing, expression, or in the giving of many valuable hints which the pages contain, he is always clear and interesting. Choirmasters may read his book with profit; they will certainly derive no little pleasure from the perusal.

Crossing the Bar. Song. Composed by William S. Hannam. [Novello, Ewer and Co.]

This setting of the Poet Laureate's well-known words is not without its good points. It exhibits due appreciation of the poetry. There is a clever modulation at the end, from $\mathrm{E}$ major to $\mathrm{E}$ flat major, which shows the composer to be possessed of some musical ability. The song is attractive, and will, doubtless, find favour with the public and take a good place in the estimation of singers. The consecutive fifths employed in the first bar of the second page, and repeated later in the song, indicate, perhaps, that the composer intended the effect they produce. There is, however, nothing gained by their use, and their introduction might easily have been avoided.

Magnificat and Nunc dimittis in the key of $F$. By George Shinn.

[Novello, Ewer and Co.]

THERE are, it is true, plenty of good settings of the Canticles of the Church suited to the capacities of unambitious choirs, but there is no reason why their number should not be increased, especially when, as in the present case, the composer know's from experience the exact thing required for the use of parish choirs, and has accomplished his task with the skill of a good musician and the reverence due to the words he has chosen to associate with sound.

\section{FOREIGN NOTES.}

ThE German version of Sir A. Sullivan's opera "The Yeomen of the Guard " ("Der Königsgardist") was, on Saturday, the $4^{\text {th }}$ ult., produced for the first time before a crowded audience at the Carl Schulze Theatre, in Hamburg, and was received with great applause.

M. Jules de Swert has completed a comic opera, entitled "Piccolino," which is to be produced this winter at Amsterdam, Rotterdam, and The Hague.
A new theatre, to be called The Eden, is to be erected at Berlin at a cost of some $£$ roo,ooo, a company having been formed for the purpose; and Herr Ronacher, of Vienna, is mentioned as the probable director.

Herr Richard Kleinmichel, already favourably known in Germany by his opera "Manon," has completed a new operatic work, "Der Pfeifer von Dusenbach," the interesting libretto of which deals with an episode in the life of a "piper" of the fifteenth century, and also introduces a picturesque scene of the "Piper's Day" at Rappoltsweiler, to which we had occasion to refer in our last month's Notes.

The production of Wagner's "Siegfried "-third part of the "Nibelungen" tetralogy-with M. Wilder's French translation, at Brussels, has been delayed on account of M. Servais's refusal to conduct the work without the full orchestral complement for which it is scored by its composer.

Anton Rubinstein is said to contemplate resigning his chair as Principal of the St. Petersburg Conservatoire ere long, owing to the incessant strain of examinations.

On the $4^{\text {th }}$ ult. the three hundredth performance of Gounod's "Faust" was recorded at the Imperial Opera of Vienna.

Two early operettas by great composers-viz., Mozart's "Bastian und Bastienne" and Mendelssohn's "Die Heimkehr aus der Fremde" ("Son and Stranger")-were produced and received with much interest last month by the "Gesellschaft der Opernfreunde" of Berlin. Mozart's little pastoral (composed in I768) had never been performed previously in public.

The recently discovered charming canzonetta for three male voices, by Carl Maria von Weber, has just been published, with added German words, by the firm of Raabe and Plotho, of Berlin.

The Royal Library of Munich has just acquired a most interesting collection of autograph letters by Orlando Lasso, hitherto in private possession. Lasso (or Lassus) was for the greater part of his career Chapelmaster to the Duke of Bavaria, and died at Munich in I594.

Handel's rarely heard Oratorio "Theodora" was performed twice by the Elbing Church Choir, under the direction of Herr Theodore Carstenn.

The performances at Bayreuth next year will comprise three representations of "Tristan und Isolde," seven of "Tannhäuser," and ten of "Parsifal," the entire series extending from July I9 to August I9. The Conductors will be Herren Levi, of Munich, and Felix Mottl, of Carlsruhe.

At the Berlin opera a new ballet, entitled "Prometheus," is in course of preparation, the author of the text being Herr Emil Taubert, and the music Beethoven's setting to "Die Geschöpfe des Prometheus." The original version of the latter being long since lost, Beethoven's music has hitherto been confined to the Concert-room; and by thus reconnecting it with the stage, the Berlin opera is undertaking a very interesting experiment.

M. P. Diaz is the composer of a new opera, "Benvenuto Cellini," which is to be brought out shortly at the Paris Opéra Comique. This is the eighth operatic work upon the subject, which was first treated, musically, by Berlioz (1838), by Franz Lachner (1840), Louis Schloesser ( 845$)$, and Lauro Rossi ( 1845$)$. In more recent years the Maëstri Orsini (1875), of Naples, and Bozzano (1877), of Genoa, have each produced a "Cellini," while M. SaintSaëns's latest opera, "Ascanio," is also concerned with the career of the great Florentine sculptor.

Signor Vianesi has definitely resigned his post as Conductor of the Paris Opéra, and M. Joseph Dupont, who wielded the baton at Covent Garden during the latter part of Mr. Gye's régime, is spoken of as his probable successor.

The excellent Concerts directed annually at the Paris Châtelet by $M$. Colonne recommenced on the Igth ult., with a programme including extracts from "Lohengrin" and "La Damnation de Faust," and Grieg's "Peer Gynt "Orchestral Suite.

M. Massenet's new opera "Werther," a dramatised version of Goethe's early novel " Werther's Leiden," is in course of active preparation at the Théâtre de la Monnaie of Brussels. 